Published as: Mahpula, A., Y. DeGang, A. Kurban \& F. Witlox (2013) "An overview of 20 years of Chinese logistics research using a content-based analysis". Journal of Transport Geography. Vol. 31, pp. 30-34.

\title{
An overview of 20 years of Chinese logistics research using a content-based analysis
}

Abduwali Mahpula ${ }^{1,2,3}$ DeGang Yang ${ }^{1}$, Alishir Kurban ${ }^{1,2}$ \& Frank Witlox ${ }^{4}$

1 Xinjiang Institute of Ecology and Geography, CAS, Urumqi 830011, Xinjiang, China

2 Graduate University of the Chinese Academy of Sciences, Beijing 100049, China

3 Xinjiang Academy of Social Sciences, Urumqi 830011, Xinjiang, China

4 Ghent University, Department of Geography, 9000 Gent, Belgium

\begin{abstract}
This paper provides an overview of logistics research that has been carried out by Chinese academics in the timeframe 1990-2010 using content-based analysis. It is shown that the study of logistics has evolved quite a bit, but that the core concern of logistics study for China's researchers is the physical movement of goods, while the primarily focus for international researchers has shifted to supply chain and management. China's approaches to the geography of logistics are however evolving, but as yet have not embraced the 'supply chain' perspectives. Here important future research opportunities can be identified.
\end{abstract}

Key words: Logistics, wuliu, China, content analysis

\section{Introduction}

China's booming economy has greatly benefited from globalization and trade liberalization in recent decades to find its niche as the world's manufacturing center and increase its geopolitical importance (McGregor, 2006). China's main export destinations are the European Union, the United States, and Japan, which together represent $59 \%$ of exports by value. Almost $43 \%$ of total imports come from Japan, the European Union, South Korea, and Taiwan. Growth in trade between China and its global trading partners has placed increasing pressure on international and domestic transport networks. This trade surge has also worsened congestion, increased delays, and exacerbated environmental problems in most Chinese ports and coastal regions (Zhang and Figliozzi, 2010). 
Today, logistics services are essential to the day-to-day operation of the Chinese economy and a major source of employment, with considerable implications for economic and social development in China. In 2010, the total value of China's logistics sector was USD 19.38 trillion, increasing by $15 \%$ year-on-year (http://www.chinawuliu.com.cn). The share of the total added value of the logistics industry in GDP (6.9\%) and China's tertiary industry (16.0\%) has been stable in the past five years, indicating that the logistics sector has managed to grow as fast as the tertiary market and the national economy. The total fixed assets investment in the logistics industry grew by $19.4 \%$ to USD 474.49 billion in 2010 . As of 2010 , China has $91,000 \mathrm{~km}$ of railways, the third largest rail network in the world, and 3,583,715 km of upgraded roads, the second largest road network worldwide. Moreover, China is the undisputed leader in inland water transport with 124,000 km of navigable water-ways. The total freight traffic of the four major modes (road, railway, water, and air) of transport was $27,806.3$ million tons in 2009 . More than $76 \%$ of cargo travels by road while $11.9 \%$ and $11.4 \%$ travel by rail and water, respectively (National Bureau of Statistics, 2011).

Providers of China's export logistics are mainly large foreign logistics companies located in the Pearl River Delta Economic Region (Shenzhen and Guangzhou), the Yangtze River Delta Economic Region (Shanghai) and the Bohai Bay Economic Rim (Beijing-Tianjin and Dalian). These include the large logistics and express suppliers and transport companies such as TNT, UPS, DHL, and FedEx. China's internal market is highly fragmented, with different types of participants including some foreignowned companies with in-house logistics operations, and Chinese-owned transport companies. China's market players can be classified into four types in terms of their structure: (a) logistics companies restructured from traditional warehousing providers and transport companies that currently have large market shares; for example, Sinotrans, COSCO, China Post, China Railway Express, CMST, and China Container; (b) newly formed state-run or state-owned logistics companies that are mainly commercial warehouse and transport players in the region; for example, China Shipping Logistics; (c) foreign (including Hong Kong) players, which entered China to extend their services to their original multinational customers; for example, Datong, Kintetsu, HAVI, Maersk, EAC, Hutchison Whampoa, Inchcape, Sea-Land, Huashang, and Sankyu; (d) emerging private entrants located across the country. This last group are flexible, low cost, high growth and the most vibrant China 3PL logistics firms; for example, PG Logistics, Jiuchuan, and Sunjet Logistics. In terms of geographical coverage, foreign companies serve a broader market area, but private and state-owned logistics firms have niches in the domestic market. Firms use different strategies to enhance their competitiveness. State-owned logistics firms put more effort into increasing service offerings, private companies have a greater need for strategic alliances, and foreign logistics firms attempt to improve responsiveness to customers to a greater extent.

One year after China's six ministries jointly issued the Document for Accelerating the Development of Modern Logistics in 2001, nearly 30 provinces and cities had formulated modern logistics planning (Wang, 2006). Hong Kong and Shanghai are the two most important logistics hubs in the country. Two other important ports are located in Shenzhen and Guangzhou, making the region around the Pearl River Delta China's most important logistics center. To bring logistics services to the north, a third Chinese logistics center in Beijing/Tianjin has been set up. China's logistics industry has developed rapidly in recent years, benefiting from China's economic development, continuous improvement of logistics technology, and constant expansion of the e-commerce market. Since implementation of the Planning for Restructuring and Revitalization of the Logistics Industry in March 2009, Chinese government policy has supported the accelerated development of China's logistics 
industry. The government is now formulating a Medium- and Long-term Development Plan of the Logistics Industry 2012-2020 that will define the directives and key highlights for the development of the logistics industry for the coming period.

Clearly logistics is essential in China. It is big business for the economy and economic growth. It is considered highly relevant and strategic for the public sector and administration. The question is whether it is also so understood and studied by the Chinese academic world. In other words, has the study of logistics evolved as well? Or, what are the key logistics research topics that have been and are being analyzed by Chinese researchers. The purpose of this paper is to provide an insight on the progress of Chinese logistics research through an application of content analysis to the recent, relevant Chinese literature.

In what follows we focus on three aspects. First we briefly outline how Chinese researchers and policy-makers understand logistics. Second, we introduce our data and methodology, and discuss the major findings. Finally, we draw some conclusions regarding setting a future logistics research agenda.

\section{Understanding Chinese 'logistics'}

Geographical research on logistical activity has a complicated relationship with transport geography in China. The concept of logistics was introduced from Europe and the United States in the early 1980s after some geographers began to notice the impact of logistics on geography (Wang, 2006).

In fact, logistics had attracted policy attention in China in June 1979. It was then that 'logistics' was referenced for the first time after Chinese delegates returned from attending an International Logistics Conference in Japan. The two Chinese characters (wù-liú) used to signify logistics originated from Japanese and are still used in China today. From the 1950s and 1970s, the term 'physical distribution' was used to describe the physical movement of goods. In 1985, the US Logistics Management Association officially changed the term 'physical distribution' to 'logistics'. To differentiate the sequence of changes between these two concepts, 'traditional logistics' refers to the former and 'modern logistics' to the latter when translated into a Chinese context. The main geographical research on modern logistics was started by geographers working in the transport geography field. Han and Wang (2004) clearly outlined the 'geography of logistics' and presented their research at the annual meeting of the geographers in China. The emergence of geographical studies of modern logistics enriched the theoretical system of transport-of-goods geography (Wang and Jin, 2005). Logistics has become one of the key areas of transport geography, and has long been included in the geography of the transport sector (Cao and Peng, 2006), but seems to have a distinct meaning that differs from a western understanding of what is logistics.

Hence, with the exception of a few, most mainland Chinese researchers (not limited to geographers) have therefore a different interpretation of what is logistics from the English word 'logistics'. This can be seen in their continued emphasis upon the traditional sense of the flow of goods in their studies which falls far short of the modern concept of logistics. This also has meant many studies in China focus on freight movements and transport (traditional logistics), with some geographical analysis of logistics parks, but miss out on supply chain management, the behavior of supply chains and their spatial implications. Chinese scholars' contributions tend to be more on macro theory and planningoriented while research done outside of China tend to be more "practical" and supply-chain- 
oriented. Without emphasizing this difference, readers in the English world would not understand why Chinese geographers have gone to a different direction.

We now turn our attention to how this development has had its effect on the intellectual thinking on the geography of logistics in China.

\section{Content analysis}

In order to provide an understanding on the development of (domestic) Chinese logistics research a content analysis was performed. Content analysis is an observational research method that is used to systematically evaluate the symbolic content of all forms of recorded communication (Kolbe and Brunette, 1991). It is a well-accepted method used in social sciences (Krippendorff, 2004), and has also been applied in logistics research (Spens and Kovács, 2006; Cullinane and Toy, 2000). Content analysis has also been used by Chinese scholars in their research on the geography of logistics and freight (Wang and Jin, 2005; Wang, 2006; Cao and Peng, 2006; Zong et al., 2010).

For the purpose of our study, and given the amount and diversity of available publications, appropriate limits had to be set. Only papers by Chinese researchers in China in the Chinese language, and published in academic journals were considered, while handbooks, dissertations and conference papers were excluded. Note that we do not want to downplay the considerable work of Chinese researchers who have contributed to the international debate on logistics via their China case studies. To account for quality, the analysis focused only on top national journals. These Chinese journals, titles translated to English were Acta Geographica Sinica, Scientia Geographica Sinica, Progress in Geography, Geographical Research, Human Geography, Economic Geography, Areal Research and Development, World Regional Studies, City Planning Review, Arid Land Geography, Yunnan Geographic Environment Research, Tropical Geography, Geo-Information Science, and Remote Sensing Information. Journals solely focusing on the logistics industry were excluded. A total of 74 journal publications were reviewed. Only 9 articles were published between 1990 and 2000, the remainder was published between 2001 and 2010 with a majority of the papers published in one of the two (leading) journals Acta Geographica Sinica and Economic Geography. Other journals provided a limited number of contributions. This in itself indicates the universality of this topic in geographical research in China.

Table 1 offers selected lists of key research topics in the geography of logistics suggested by some researchers in China. Lv and Yan (2003) argued that five research topics would most effectively reflect the geography of logistics; Han and Wang (2004) suggested six research agendas for an initial geography of logistics; Pan and Chen (2007) suggested five topical areas that should be the major focus of the geography of logistics.

Table 1. Research objects in geography of logistics according to some researchers in China

\begin{tabular}{|l|ll|}
\hline Lv and Yan (2003) & 1. & Geographical basis of logistics activities \\
& 2. & Spatial distribution of logistics \\
& 3. & Configuration of the logistics infrastructure \\
& 4. & Spatial characteristics of logistics flow and the projections of the flow \\
& 5. & Construction and planning of logistics centres \\
\hline
\end{tabular}




\begin{tabular}{|l|ll|}
\hline Han and Wang (2004) & 1. & Relationship between logistics activities and the geographical environment \\
& 2. & Geographical distribution and spatial heterogeneity of logistics activities \\
& 3. & Regional organization and planning of logistics activities \\
& 4. & Flow rule of logistics activities \\
& 5. & Evolution and the formation mechanism of a logistics economy \\
& 6. & Logistics management and software development \\
\hline Pan and Chen (2007) & 1. & Theories and methods of logistical geography \\
& 2. & Spatial organization form of logistics activities and its regional variations \\
& 3. & Occurrence, development, and distribution characteristics of industrial logistics \\
& 4. & Urban and rural logistics system planning (including the planning and design of logistics \\
& 5. & Organdes and distribution lines) \\
\hline
\end{tabular}

An examination of the different lists in Table 1 indicates that research topics in the geography of logistics in China are mainly concerned with the spatial characteristics of logistics activities, the regional and organizational planning of the logistics system, industrial lay-out, and the distribution management of logistics activities. There seems less attention to the organizational and functional dimensions apparent in the international view outlined earlier. Rather, the attention centers on research relating to industrial development and regional planning. In a way, China's researchers are still on the path of convergence with Western research and theory. For example, we could not find any specific discussions of the evolution of supply chain perspectives and their impacts upon the geographical dimensions of logistics in the Chinese geographical literature. The only object of relevance discussed here was the concept of logistical friction. However, it is clear that the geography of logistics has attracted considerable interest and a more broadly based research framework is now emerging.

Domestic applied research has been spurred by the planning needs of China's logistics industry, and has used the research paradigm of transport geography and to some extent Western theory to explore the issues. According to the content analysis of the papers that were reviewed most applied research is driven by two main factors: policy and markets.

Because of its centralized economic management system, China's regional, industrial development has remained under strong policy guidance and academic work reflects that situation. When logistics became a serious issue in government policy several years ago, many geographers enjoyed significant policy salience and attracted considerable research funding. That funding produced papers that focused on three levels of spatial analysis, that is, on national, regional, and urban scales. Studies on the national scale have discussed development strategies for the logistics industry and spatial structure of a logistical economy (Chen and Yang, 2001; Han et al., 2002; Liu, 2004; Wang, 2005). Most of these studies highlighted the contacts between the spatial network and organizations of domestic logistics activity. Studies on domestic regional integration have focused on coastal interprovincial logistics and city group logistics. Scholars have conducted empirical research on network building and regional competitiveness of the Bohai Sea, the Shandong Peninsula city group, and integration of Guangzhou-Shenzhen-Hong Kong logistics (Wang and Han, 2004; Sun and Wei, 2008; Zhou and Zhou, 2009). Using the theory and methods of national as well as interprovincial analysis scholars conducted case analysis of city-level logistics in Shenzhen, Qingdao, Dalian, Harbin, and Beijing (Gao, 2004; Zhao, 2004; Zhao and Wang, 2005; Guo and Han, 2006; Zhu and Xiang, 2006; Zhang and Bai, 2010). These projects generally focused on industrial planning, spatial competition, and the facility lay-out of urban logistics firms. 
Because China's coastal region is the main base of national export-import activities and logistics activities, port logistics attracts much research interest. Scholars have used empirical research methods to analyze international port logistics, integrated logistics of port areas, domestic docking, and the port logistics market (An and Han, 2001; Tian and Zhang, 2004; Wang, 2007; Huang and Wang, 2008; Li and An, 2008; Meng, 2008). In recent years, scholarly interest in airport logistics of coastal regions has increased. Scholars have discussed the logistical effects of the new Baiyun Airport in Guangzhou and the functional lay-out of airport logistics parks in Shanghai and Hangzhou (Yang and Yan, 2002; Gu and Xia, 2008). Some researchers have attempted to study the industrial organization of logistics in the growing markets in coastal regions. Han and Li (2006) analyzed the factors influencing the location of 3PL logistics enterprises in Dalian from a theoretical perspective and concluded from their case study that consumer demand, policy, competition, and transport are the four key factors for 3PL location choice. Xie and Li (2005) presented a case study analyzing logistics firms in Suzhou city. They demonstrated not only that the development of logistics firms in Suzhou city involved micro-enterprise operations but also that more attention should be paid to macro-geographical factors. Wang's (2008) case study analyzed the spatial network of logistics firms in China and discussed their spatial system, function ties, and operation mechanisms.

Zong et al. (2009) aimed for a microscopic understanding of the organization of the logistics industry in urban China using the South Logistics Enterprises Group as a study case. It was observed that the strategic networks of logistics firms in China covered two types: one is the alliance between logistics firms and their customers; the other is the alliance between new logistics firms and other small or medium-sized traditional logistics firms. Mo et al. (2010) collected data from 3,040 transportoriented logistics enterprises in Guangzhou city, and studied their spatial distributions and agglomeration mechanisms in different districts of the city.

There have been only a few studies on inland port logistics (Liu and Zhang, 2005). Most of the railway studies that involved logistics activities in China have been conducted from an economic perspective, and only a few of these studies have used the methods of geography.

Regarding methodologies and approaches used, China's researchers are using GIS, spatial planning and spatial interaction models. GIS technology solves visualization problems in logistics management. Studies have focused on the decision support functions of logistics centers, the flow of information in logistical management, construction and distribution models, traceability of logistical information, and the integration of GIS, GPS, GSM and the Internet (Pan, 2007; Liu and Hu, 2004; Yang and Sheng, 2009; Yue et al., 2007; Qu et al., 2008; Cai, 2002). In addition to the main GIS analysis, scholars have also made extensive use of mathematical models, data modeling, and specialized software systems. Scholars have discussed planning indicators of modern regional logistics, Voronoi diagrams to delimitate distribution center service coverage, combinations of forecasting models for predicting regional logistical demand, and a model of regional logistical development (Wang et al., 2003; Feng, 2010; Zhu, 2008; Li et al., 2006). Regarding spatial interaction models of logistics, some scholars have combined logistical theory and geographical models to discuss the spatial interaction of logistics based on the Wilson model (Li, 2008). Some researchers have computed and drawn regional logistics resistance surface maps with the model of minimum cumulative resistance (MCR) (Feng and Lv, 2007). Empirical and case study applications in industrial organization are emerging and their insight will provide a new impetus to the analysis of logistics activity. 
In summary, Chinese scholars are actively exploring regional-scale logistics and adapting them to the reality of China's economic geography. In this way China's domestic geographers have made certain contributions in logistics to national, regional, and city planning.

\section{Looking to the future}

The development of geographical research in logistics in China has been shaped by domestic economic realities and an established understanding within transport geography. Whether performed at the basic theoretical level or at the methodological level, geographical studies have had a significant impact on the analysis of logistics. Geographical research in the field is mainly carried out by researchers affiliated with transport geography, whose related research area was found to be regional planning and industrial analysis, generally focussed upon coastal regions. Our contentbased analysis shows that China's geographical research on logistics exhibits a number of typical characteristics and weaknesses ${ }^{1}$. In overview, from the aspect of basic theory, it seems China's researchers are more concerned with applying an established study framework from the discipline than with the basic conceptual development that is more apparent in the work of western researchers.

This review suggests the core concern of logistics study for China's researchers remains the physical movement of goods, while the primarily focus for international researchers is now on supply chain and management. The target characteristics of spatial studies in China are typically aimed more at macro research and planning, while international studies are more closely concerned with production-consumption networks and cost targeting. Overall, China's approaches to the geography of logistics are still evolving, but as yet have not embraced the 'supply chain' perspectives.

In our opinion, future studies in China require the expansion of several areas of applied research.

First, the geography of inland logistics and export-oriented logistics must be explored in depth. In response to rising wages and land prices in the coastal regions, companies are increasingly moving their manufacturing facilities into the country's interior. This shift particularly benefits inland waterway shipping and road transport. However, dated infrastructure and a lack of adequate highway networks connecting the developed coastal regions to underdeveloped inland provinces increase rail and river congestion (Mongelluzzo, 2007). Forward-looking research and follow-up studies of inland logistics industries and city logistics clusters are required. In the context of China's desire to maintain its 'world factory' status, industrial products will become more dependent on ingoing raw materials and the efficiency with which finished goods can be shipped out to markets. Such logistical studies based on these trade links could have great strategic significance.

Second, the geography of supply chain networks is another area that requires expansion. Here it will be necessary to draw upon interdisciplinary perspectives, especially including management studies. The evolution of the Chinese economy from low cost manufacturing into higher value products and processes will require tailored and efficient logistics, value-added services, and flexible supply chain management. Meanwhile, as the Chinese logistics and transport market matures, consolidation

\footnotetext{
${ }^{1}$ The present analysis therefore cannot be said to provide clear evidence of the existence of something approaching a distinctly Chinese research paradigm. Furthermore, our paper may contribute to a better understanding of China's progress by expanding the scope of this content analysis to include all the work in China being published 'outside', even by Chinese-based researchers.
} 
among firms could occur, which is likely to lead to the emergence of global-scale Chinese transport and logistics companies, as has happened in shipping and air transport. Hence the scale of analysis will need to embrace microenterprises through to macro regional distribution arrangements.

Finally, the spatial effect of logistics regulation must be explored. In sharp contrast to the booming market, the China logistics sector is underdeveloped and not yet standardized. It imposes logistics costs on businesses of up to $21 \%$ of the product costs, more than twice the average for developed markets (Waters, 2007). Operating costs including fuels, rental, etc., are surging in China.

Connections between railway, road, and port facilities still have much room for improvement. The overcharging of road tolls adds extra costs to logistics service providers. There is poor communication and co-ordination between the Ministry of Transport, Ministry of Railway, and Civil Aviation Administration that regulate highways, railways, and airways, respectively (Chung, 2007). Despite a reduction in national-level regulations since China's entry into the WTO, local governments continue to set up bureaucratic and regulatory barriers to protect local businesses or products and prevent the entry of outside competitors. Municipal governments also compete to attract logistics hubs and infrastructure. This local protectionism is driven by the desire to maximize local economic growth, employment, social stability, and tax revenues, and less by concern about the efficient utilization of regional resources or the creation of an integrated national transport network (Jiang and Prater, 2002). With respect to these issues, studies on the spatial effect of logistics regulation at different geographical levels will be very significant in shaping policy changes.

\section{Acknowledgements}


The authors would like to thank the anonymous reviewers for their comments, and would like to express their appreciation for the help and comments received from the Associate Editor Kevin $\mathrm{O}$ 'Connor. All remaining errors are ours.

\section{References}

An Y P, Han Z L 2001. The coming of the logistics times and the development of port function. Tropical Geography, 21(3): 276-281.

Cai S H 2002. The research and analysis of web based spatial logistics information system. Geoinformation Science, 4(1): 104-107.

Cao X S, Peng $L L$ 2006. A review of transportation geography of China during the last ten years. Human Geography, 21(3): 104-108.

Chen J, Yang K Z 2001. Development strategies of China's logistics industry in e-commerce environment, Economic Geography, 21(5): 554-558.

Chung O 2007. Hong Kong SMEs Withdraw from Mainland China. Asia Times Online, Jun 62007.

Cullinane K, Toy N 2000. Identifying influential attributes in freight route/mode choice decisions: a content analysis. Transportation Research E, 36(1): 41-53

Dicken, P 2007. Global Shift. London: Sage.

Feng S M 2010. Study on service coverage of distribution center based on Voronoi diagram. Areal Research and Development. 29(3): 142-144.

Feng B, Lv C Y 2007. A study on resistance surface model of logistics of fishing harbors in Western Guangdong. Tropical Geography, 27(3): 245-248.

Gao H 2004. On logistics industry development and countermeasure analyses in Shenzhen. Economic Geography, 24(1): 35-38.

Gu Z, Xia N K 2008. The research of the functional arrangement of airport logistic park. Economic Geography, 28(2): 283-285.

Guo J K, Han Z L 2006. Modern logistics industry and urban spatial reengineering of port city - a case study of Dalian. Human Geography, 21(6): 80-86.

Han Z L, Li X N 2006. Position influencing factors third-party logistics enterprise. Areal Research and Development, 26(2): 16-19.

Han Z L, Wang C J, Long F 2002. The characters of the development and distribution about Chinese logistics and the discussion of the developing measures. Progress in Geography, 21(1): 81-90.

Han Z L, Wang C J 2004. The rise of China's geography of logistics and freight studies and its development. Development strategy and theory building of geography-Century Retrospect and Prospect. Beijing: Commercial Press, 399-410. 
Huang M S, Wang C C 2008. Development of port logistics industry and the port logistics link between Fujian and Taiwan. World Regional Studies, 17(1): 105-111.

Jiang B, Prater E 2002. Distribution and logistics development in China: The revolution has begun. International Journal of Physical Distribution \& Logistics Management, 32(9): 783-798.

Kolbe R, Brunette M 1991. Content analysis research: An examination of applications with directives for improving research, reliability and objectivity. Journal of Consumer Research, 18(2): 243-250.

Krippendorff K 2004. Content Analysis. An Introduction to its Methodology. Thousand Oaks: Sage.

Li H J, Xie W J, Cao Y H 2006. The IGJAHP evaluates model of logistics development and the analysis of spatial structure for Anhui province. Economic Geography, 26(2): 220-224.

Li H Q 2008. Spatial interaction of logistics based on Wilson model. Economic Geography, 28(4): 588591.

Li X G, An W X 2008. The researches on the space layout of international trade logistics of the agricultural products based on the port resources of Shandong Peninsula and its optimization. Areal Research and Development, 27(4): 20-25.

Liu C L 2004. Empirical analysis on the spatial structure of logistical economic linkages in China mainland, Economic Geography, 24(6): 826-829.

Liu H Y, Zhang X L 2005. Analyze and research of the modern logistics industry development in Alashankou region, Arid Land Geography, 28(3): 404-408.

Liu M Z, Hu L Q 2004. The studies on architecture of spatial logistics information platform based Applet-CORBA. Geo-information Science, 6(3): 29-33.

Lv L C, Yan X P 2003. Modern logistics and economic geography. Areal Research and Development, 22(2): 5-7.

National Bureau of Statistics 2011. Yearbook 2011. Beijing: National Bureau of Statistics.

McGregor R 2006. The trillion dollar question: China is grappling with how to deploy its foreign exchange riches. Financial Times, September 252006.

Meng S D 2008. The game analysis of port logistics market of Shanghai Yangshan harbor. Areal Research and Development, 27(4): 52-55.

Mo X, Qian Q L 2010. Spatial distribution features of the transportation-oriented logistics enterprises in Guangzhou . Tropical Geography. 30(5): 521-527.

Mongelluzzo, B 2007. How the west will be won. Journal of Commerce, Monday, October 222007.

Pan Y J, Chen Z N 2007. Comments on the research of logistics geography. Yunnan Geographic Environment Research, 19(6): 91-95.

Pan W A 2007. Study on demarketing location of distribution center based on DSS of GIS. Economic Geography, 27(1): 56-59. 
Qu X H, Zhuang D F, Yue D S 2008. Construction and application of GIS based greenstuff traceability logistics system. Geo-information Science. 10(5): 615-622.

Spens K, Kovács G 2006. A content analysis of research approaches in logistics research. International Journal of Physical distribution and Logistics Management. 36(5): 374-390.

Sun F H, Wei X 2008. The core competence of logistics industry development in Shandong Peninsula city group. Acta Geographica Sinica. 63(10): 1108-1118.

Tian R G, Zhang Z K, Zhu D K 2004. Study on the coastal harbor industry marine logistics and globescale production, World Regional Studies, 13(2): 1-8.

Wang C J 2005. Model about spatial organization of logistical economy in China. Economic Geography, 25 (3): 366-368.

Wang C J 2006. Geographical study on modern logistics and its development trend. Human Geography, 21(6): 22-26.

Wang C J 2007. Evolution and developing mechanism of port distribution system in China. Acta Geographica Sinica, 62(8): 809-820.

Wang C J 2008. Spatial organizational network of logistics company in China. Acta Geographica Sinica, 63(2): 135-146.

Wang C J, Han Z L 2004. The formation and operating model of logistics net in the region around Bohai sea. Human Geography, 19(2): 69-73.

Wang C J, Jin F J 2005. Research history and developing trend about geography of transportation in China. Progress in Geography, 24(6): 66-78.

Wang L, Han Z L, Li Y J 2003. A research on basic theories frame of modern regional logistics programming. Economic Geography, 23 (5): 601-605.

Waters D 2007. Global Logistics New Directions in Supply Chain Management, London and Philadelphia: Kogan Page.

Xie W J, Li H J 2005. Development route and strategic choice of logistics in Suzhou. World Regional Studies, 14(2): 51-56.

Yang F, Yan X P 2002. An analysis on the new airport and the developments of logistics in Guangzhou. Tropical Geography, 22(3): 208-213.

Yang L, Sheng Y H 2009. Design and implement of logistics information system for small \& medium enterprise. Journal of Geo-information Science. 11(5): 652-656.

Yue W H, Shi K, Huang Y H 2007. Design and realization of GIS- based logistics distribution system. Yun Nan Geographic Environment Research, 19(3): 72-76.

Zhang Y Z, Bai J Y 2010. Public logistic area planning: a case study of spatial planning for public logistic area in Beijing. City Planning Review, 34(11): 31-39. 
Zhang Z Y, Figliozzi M A 2010. A survey of China's logistics industry and the impacts of transport delays on importers and exporters. Transport Reviews, 30(2): 179-194.

Zhao J J 2004. Study on the spatial competition confronted by Qingdao logistics development. Human Geography, 19(2): 64-68.

Zhao X Z, Wang L 2005. Discussion on the urban storage establishment and methods in the modern logistics environment programming principle - a case study of Dalian, Areal Research and Development, 24(6): 52-55.

Zhou P D, Zhou J Q 2009. Logistics industry in Guangzhou, Shenzhen and Hong Kong and its relationship to economic growth in the Pearl River Delta city groups. Tropical Geography. 29(1): 3742.

Zhu B Z 2008. A novel combined forecasting model for the prediction of regional logistics demand. Economic Geography, 28(6): 952-954.

Zhu Q W, Xiang W 2006. Core city logistic system planning of Northeast old industrial base. Areal Research and Development, 25(5): 14-17.

Zong H M, Zhou S H, Yan X P 2009. Organization of logistics network on firm level-a case study of the South Logistics Enterprises Group. Scientia Geographica Sinica, 29(4): 477-484.

Zong H M, Zhou S H, Yan X P 2010. Progress in the logistics study and its implications for China: an economic geographical perspective. Progress in Geography. 29(8): 906-912. 